\title{
HUMAN RIGHTS OR THE RULE OF LAW- THE CHOICE FOR EAST AFRICA?
}

\author{
Craig A. Stern*
}

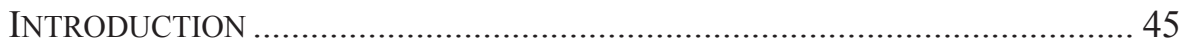

I. THE RULE OF LAW AND EAST AFrICA …........................................... 46

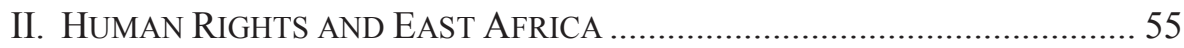

III. EAST AFRICA, HUMAN RIGHTS, AND THE RULE OF LAW ....................... 66

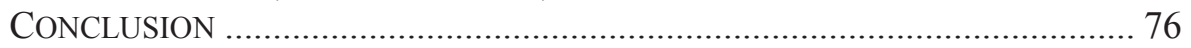

\section{INTRODUCTION}

The world over, what political cause is celebrated more than human rights? The rule of law, perhaps. These two noble and important objects of civil government - both valued as of inestimable worth these daysusually are complementary. Human rights are insecure without the rule of law to protect them, and what human right is more fundamental than the right to be treated in accordance with the law and not the whim of the mighty? Human rights and the rule of law seem to stand together. How then, when human rights and the rule of law stand opposed, and in circumstances where they most need each other's mutual support and meet opposition enough from other forces?

It is the thesis of this article that in East Africa human rights and the rule of law very likely stand opposed and cannot coexist. To be sure, some human rights can coexist with some notion of the rule of law in East Africa, as elsewhere. But for East Africa to play host to the full panoply of human rights as commonly supported by the international community and endorsed by East African nations themselves, and at the same time to play host to a rigorous practice of the rule of law, appears to be something that simply cannot be done.

* C 2015 Craig A. Stern. Professor and Executive Director of the Center for Global Justice, Human Rights, and the Rule of Law, Regent University School of Law. The author thanks for their generous assistance Jeff Brauch, Mary Bunch, Matt Mogish, Scott Pryor, Ernie Walton, and Eric Welsh. 
The argument of this article is straightforward. Part I describes the rule of law, its importance, and (briefly) its treatment in East Africa. Part II describes human rights, their two major divisions, and (briefly) their treatment in East Africa. Part III explains how the rule of law and human rights collide in East Africa. The conclusion suggests that this collision is the result of an extravagant Western imperialism that has helped deprive East Africa both of human rights and of the rule of law.

\section{THE RULE OF LAW AND EAST AFRICA}

The rule of law is today more talked about in more places by more people than perhaps ever in its history, but that does not mean it is any clearer in meaning or significance, or better understood. Indeed, the term has been put to so many uses in recent years that it is difficult to see how anyone will ever be able plausibly to claim to have cornered the market. ${ }^{2}$

2. Martin Krygier, Inside the Rule of Law, 3 Rivista Di Filosofia DEL DiRITto 77, 77 (2014) (It.). As to the current celebrity of the rule of law, Amichai Magen has this to say:

At the outset of the twenty-first century, the rule of law is no longer a concept exclusively, or even primarily, defined and debated by political philosophers and constitutional lawyers, as had been the case in centuries past. Over the last decade [i.e., approximately the first of the third millennium] in particular, the rule of law has become "the motherhood and apple pie of development economics." Western democracies, their regional organizations, NGOs, and the multilateral development agencies they control, now pour billions of dollars and euros into projects designed to measure the rule of law, create it where it does not exist-in closed dictatorships, failed states, and post-conflict zones - and to strengthen it in traditional and struggling democracies around the globe. Institutionalists of different hews [sic] have come to see it as central to modern statehood, impartial economic exchange, and objective justice. Democracy scholars are pointing to it as the essential, non-electoral dimension of democratic substance. Together with human rights and democracy, the rule of law is now upheld by liberal internationalists as a central pillar in the "virtuous trilogy" upon which a legitimate international order rests, while international 
Indeed, the rule of law enjoys a superfluity of definitions. The major distinction among them, however, is simple enough. It is the distinction between formal definitions and substantive definitions. ${ }^{3}$ Formal definitions speak of civil government constrained by rules and of courts with power to apply these rules to government actors. Substantive definitions, going beyond the formal, speak also of the content of the rules, so that the rules embody principles of justice such as human rights. These two general types of definitions of the rule of law are to be found even in perhaps the earliest discussion of the rule of law, that of Aristotle: "We have to distinguish two senses of the rule of law-one which means adherence to such laws as have been enacted, and another which means that the laws obeyed have also been well enacted." 4

A classic statement of the formal version of the rule of law appears in F.A. Hayek's The Road to Serfdom:

Nothing distinguishes more clearly conditions in a free country from those in a country under arbitrary government than the observance in the former of the great principles known as the Rule of Law. Stripped of all technicalities, this means that government in all its actions is bound by rules fixed and announced beforehand-rules which make it possible to foresee with fair certainty how the authority

security experts have come to see it as indispensable to ending civil wars, building durable peace, and fighting insurgencies, transnational crime, and terrorism.

Amichai Magen, The Rule of Law and Its Promotion Abroad: Three Problems of Scope, 45 StAN. J. INT'L. L. 51, $52-53$ (2009) (footnotes omitted); see also id. at 82 (noting newfound popularity of the rule of law). As to the multiplicity of meanings of the rule of law, he notes, "Notwithstanding its pervasiveness as an ideal ... the term is afflicted by an extraordinary divergence of understandings." Id . at 55.

3. See Ronald J. Daniels \& Michael Trebilcock, The Political Economy of Rule of Law Reform in Developing Countries, 26 MicH. J. INT'L L. 99, 104-07 (2004). Sometimes the literature calls the formal definitions "thin" and the substantive "thick." So, by way of example, for a tale of the recent thickening of the concept of the rule of law from its classically thin state, see Magen, supra note 2, at 58-63.

4. Aristotle, The Politics of Aristotle 175 (Ernest Barker trans., Oxford Univ. Press 1971-72) (1946) (IV, viii, § 5; 1294a). For a short historical and theological review of the rule of law, including its treatment in the works of Aristotle, see Craig A. Stern, The Common Law and the Religious Foundations of the Rule of Law Before Casey, 38 U.S.F. L. REV. 499 (2004). 
will use its coercive powers in given circumstances and to plan one's individual affairs on the basis of this knowledge. Though this ideal can never be perfectly achieved, since legislators as well as those to whom the administration of the law is entrusted are fallible men, the essential point, that the discretion left to the executive organs wielding coercive power should be reduced as much as possible, is clear enough. While every law restricts individual freedom to some extent by altering the means which people may use in the pursuit of their aims, under the Rule of Law the government is prevented from stultifying individual efforts by ad hoc action. Within the known rules of the game the individual is free to pursue his personal ends and desires, certain that the powers of government will not be used deliberately to frustrate his efforts. ${ }^{5}$

Hayek's definition of the rule of law is formal in that it prescribes how law should operate generally rather than prescribing any particular content of the law. It is the certainty, stability, and notoriety of the law that matters, not the merit or justice of its requirements. ${ }^{6}$

Slightly enlarging Hayek's definition, though still squarely within the formal division of definitions of the rule of law, is one from Brian Tamanaha:

5. F.A. HayeK, The Road to Serfdom 112-13 (Bruce Caldwell ed., definitive ed. 2007) (footnote omitted). Hayek explains later that the rule of law is not simply the mere accord with positive law. Unless the positive law possesses the qualities he describes in the paragraph quoted above, legality falls short of the rule of law. See id. at 119. See Kevin E. Davis \& Michael J. Trebilcock, The Relationship between Law and Development: Optimists versus Skeptics, 65 Aм. J. CoMP. L. 895, 913-14 (2008), for a brief description of two other formal versions of the rule of law similar to that of Hayek, those of Lon Fuller and Joseph Raz.

6. The author is reminded of a conversation he enjoyed over a picnic lunch with Malcolm Muggeridge and a few others during which Muggeridge impishly remarked that he had rather be governed by Joseph Stalin than by Eleanor Roosevelt because under Stalin one at least knew where one stood. 
The rule of law means that government officials and citizens are bound by and abide by the law.

This definition requires that there must be a system of laws - and law by its nature involves rules set forth in advance that are stated in general terms. A particular decision or an order made for an occasion is not a rule. The law must be generally known and understood. The requirements imposed by the law cannot be impossible for people to meet. The laws must be applied equally to everyone according to their terms. There must be mechanisms or institutions that enforce the legal rules when they are breached. ${ }^{7}$

Tamanaha makes explicit what surely must be implicit in Hayek's definition of the rule of law: The laws must speak in general terms, be applied to all generally, and be such that they can be obeyed. What he adds to these is the element of enforcement. The rule of law requires that the law in fact rule. Other similar definitions mention the role of courts in applying the law. ${ }^{8}$ At least one definition, attempting to describe what the rule of law means in the American context, includes the notion that persons aggrieved by certain government decisions have the opportunity to state their cases before independent decision makers whose decisions are to be well justified. ${ }^{9}$ All these definitions of the rule of law share the formal approach. General, prospective, publicized rules are to regulate the relations between civil government and others, whatever the content of those rules.

Contrast such a formal understanding of the rule of law with a substantive understanding that brings within its ambit some constraint on

7. Brian Z. Tamanaha, The History and Elements of the Rule of Law, 2012 SING. J. LeGAL STUD. 232, 233 (2012).

8. See, e.g., Richard A. Epstein, The Perilous Position of the Rule of Law and the Administrative State, 36 Harv. J.L. \& PuB. Pol'y 5, 6 (2013); John Mukum Mbaku, Providing a Foundation for Wealth Creation and Development in Africa: The Role of the Rule of Law, 38 BROOK. J. INT'L L. 959, 988-89 (2013).

9. Harry W. Jones, The Rule of Law and the Welfare State, 58 Colum. L. REV. 143,145 (1958). 
the content of law. A well-known and well regarded version of this type of understanding appears in a seminal essay by Thomas Carothers:

The rule of law can be defined as a system in which the laws are public knowledge, are clear in meaning, and apply equally to everyone. They enshrine and uphold the political and civil liberties that have gained status as universal human rights over the last half-century. In particular, anyone accused of crime has the right to a fair, prompt hearing and is presumed innocent until proved guilty. The central institutions of the legal system, including courts, prosecutors, and police, are reasonably fair, competent, and efficient. Judges are impartial and independent, not subject to political influence or manipulation. Perhaps most important, the government is embedded in a comprehensive legal framework, its officials accept that the law will be applied to their own conduct, and the government seeks to be lawabiding. ${ }^{10}$

Observe that the italicized sentence takes the definition of the rule of law beyond the formal to include the general protection of human rights. It is said that most scholarly definitions of the rule of law embrace such substantive elements, with those in the field of foreign-policy embracing human rights specifically. ${ }^{11}$ The maximalist substantive versions of the rule of law remind one of the second of Aristotle's descriptions ${ }^{12}$ :

The rule of law signifies "the empire of laws and not of men": the subordination of arbitrary power and the will of public officials as much as possible to the guidance of laws made and enforced to serve their proper purpose, which is the public good ("res publica") of the community as a whole. When positive laws or their interpretation or enforcement serve other purposes, there is no rule of law, in its fullest

10. Thomas Carothers, The Rule of Law Revival, 77 ForeIGN AfF., Mar.-Apr. 1998, at 95, 96 (emphasis added).

11. Rosa Ehrenreich Brooks, The New Imperialism: Violence, Norms, and the "Rule of Law," 101 MicH. L. REV. 2275, 2284 n.43 (2003).

12. See ARISTOTLE, supra note 4 and accompanying text. 
sense, but rather "rule by law"-mere legalism—in service of arbitrary power. ${ }^{13}$

Similar is the notion that the rule of law requires the positive law to align with the natural law. As Harold Berman explained, "The Rechtsstaat was to govern by law and was to be bound by, and not absolved from, the law which it made." ${ }^{14}$ But "Rechtsstaat . . . is rule by law, not rule of law; it does not presuppose a fundamental law which is derived from a source outside the state and which the state is legally powerless to change." ${ }^{\prime 15}$ Such an approach to the rule of law is not satisfied with the regime described by Hayek and Tamanaha. ${ }^{16}$ It is not enough that civil government adhere to rules that are stable, general, and published. The rules must also accord with principles of justice or there is no rule of law.

Clearly, the formal and the substantive - sometimes called the "thin" and the "thick" — - versions of the rule of law differ significantly. The substantive adds to the formal the requirement that civil government secure further elements of justice. The substantive, then, builds upon the formal. Whether the rule of law itself should include such additional, substantive requirements is a matter of some dispute. On the one hand, a rule of law assuring that a civil government uniformly follow iniquitous positive law may not be so golden a met-wand. ${ }^{18}$ As Professor Berman observed, "[t]heoretically, a fascist or other dictatorial regime can constitute a Rechtsstaat [i.e., a regime adhering to the 'thin' rule of law $\left.{ }^{19}\right]$. Indeed, under German national socialism jurists defended the

13. Mortimer N.S. Sellers, What is the Rule of Law and Why is it so Important? 3 (Univ. Balt. Sch. Law Legal Research Paper No. 2015-15, 2014), available at http://ssrn.com/abstract=2445057.

14. Harold J. Berman, The Struggle for Law in Post-Soviet Russia, in WeSTERN Rights? Post-Communist Application 41, 47 (András Sajó ed., 1996).

15. Id. at 48 .

16. See supra notes 5, 7 and accompanying text.

17. See, e.g., Krygier, supra note 2, at 78.

18. Sir Edward Coke called English law a "golden met-wand" that measures human acts uniformly and authoritatively - an instrument of the rule of law. Prohibitions del Roy, (1608) 77 Eng. Rep. 1342 (K.B.); 12 Co. Rep. 63.

19. See supra notes 3, 4, 14 and accompanying text. 
sentencing of persons to concentration camps on the ground that the German state was a Rechtsstaat." ${ }^{20}$ On the other hand,

[I]f excessively thin conceptions often seem urgently in need of a feed, to enable any distinction between the rule of law and law in general, thick theories are commonly vulnerable to Joseph Raz's charge that:

[I]f the rule of law is the rule of the good law then to explain its nature is to propound a complete social philosophy. But if so the term lacks any useful function. We have no need to be converted to the rule of law just in order to discover that to believe in it is to believe that good should triumph. ${ }^{21}$

To define the rule of law to include human rights and democracy, Professor Tamanaha remarks, "smacks of stuffing the meaning of the rule of law with contestable normative presuppositions to produce a desired or presupposed outcome which is then imposed on everyone by definitional fiat." 22 However that may be, it is enough for the purposes of this article to emphasize that the substantive definitions of the rule of law incorporate the formal as well. Consequently, if a legal system fails to meet the standards of the formal version of the rule of law, it fails to meet the standards of the substantive version also.

Furthermore, when it comes to including human rights in the substantive version of the rule of law, the very definition of the rule of law may make of it something out of reach. If, as this article argues, a civil government implementing a broad spectrum of human rights courts violating the formal version of the rule of law, the substantive version in this context approaches an oxymoron. How convenient, then, for regimes that slight the rule of law to hide behind a definition of the rule of law that itself helps excuse their violations. But if guaranteeing human rights may put the rule of law at risk, apart from the rule of law there can be little security for human rights. However generous a government's law

20. Berman, supra note 14, at 48.

21. Krygier, supra note 2, at 78 (quoting JOSEPH RAZ, The Rule of Law and its Virtue, in The Authority of LAw 210, 211 (1979)).

22. Tamanaha, supra note 7, at 234. 
on human rights, that generosity is but idle if the government does not respect the law. ${ }^{23}$

The very definition of the rule of law makes its universal importance obvious. And of late, "[t]he concept is suddenly everywhere-a venerable part of Western political philosophy enjoying a new run as a rising imperative of the era of globalization." 24 Brooks has observed that promotion of the rule of law commands the support of three (nonexclusive) groups involved in the quest for development: the investment community, human rights activists, and those concerned with security. ${ }^{25}$ There may be reason to doubt that the rule of law itself is so powerful a tool of development. ${ }^{26}$ All told, however, evidence demonstrates that the rule of law does in fact foster economic development at the least. ${ }^{27}$

If the rule of law is important to development, East Africa is in sore need of the rule of law. Africa generally still awaits sound development. $^{28}$ At the same time, and likely as a cause of its underdevelopment, Africa generally still awaits institutions effectively supporting the rule of law. ${ }^{29}$ Official corruption - a thing at odds with the rule of law-is endemic. ${ }^{30}$ South Sudan, for example, has seen billions of dollars looted from its treasury by senior officials. ${ }^{31}$ The law does not

23. "[I]n the realm of human rights, ... the rule of law ... is now offered as the key to the effective attainment of those rights." Magen, supra note 2, at 82.

24. Carothers, supra note 10, at 95.

25. See Brooks, supra note 11, at 2276-77.

26. See Kevin E. Davis, What Can the Rule of Law Variable Tell Us About Rule of Law Reforms?, 26 Mich. J. INT'L L. 141, 160-61 (2004).

27. See Daniels \& Trebilcock, supra note 3, at 100-02; Davis \& Trebilcock, supra note 5, at 896-905, 938-45; Magen, supra note 2, at 64.

28. See Mbaku, supra note 8, at 959-60.

29. See id. at 963.

30. Id. at 993-94, 1015-16.

31. Id. at 999 n.121, 1033. Similarly, it has been reported of Kenya that "corruption accounts for about eight percent of the country's GDP; indeed, the names of honest ministers and senior government officials in [the government of a named president] 'would fit on the back of a postage stamp.'” Nsongurua J. Udombana, Keeping the Promise: Improving Access to Socioeconomic Rights in Africa, 18 BufF. Hum. RTs. L. ReV. 135, 164 (2012) (footnotes omitted) (quoting Martin Meredith, The State of Africa: A History of Fifty Years of IndePEndence 688 (Penguin Books 2006)). 
afford mechanisms for citizens to hold such officials accountable. ${ }^{32}$ Rather, "many Africans view their present legal and judicial institutions as alien impositions designed for the benefit of the ruling elites." 33 This alienation from law and civil government, exacerbated by the ethnic and religious diversity in Africa, ${ }^{34}$ offers its own challenge to the rule of law:

Citizens must see the law as an instrument that they can use to deal effectively with everyday problems, including organizing their lives and peacefully resolving conflicts, including those that arise from trade and other forums of free exchange. If, however, citizens view the laws and institutions as "alien" impositions, used by the political elites to oppress and exploit them, they are more likely to refuse to recognize these laws, let alone obey them. Within such a context, compliance becomes very difficult - the police and other enforcement agencies may be totally overwhelmed and simply unable to perform their constitutionally assigned functions, effectively allowing society to degenerate into chaos and violence. ${ }^{35}$

With civil government detached from actual governance, the rule of law can have no real life. Law must truly regulate the relationship between a civil government and its people for the rule of law to exist. A state of civil lawlessness is not the rule of law, however much what passes for the institutions of civil government may by themselves accord with the law. Playing a game according to the rules does nothing to bring rules to spectators. Moreover, if government actors in East Africa do not respect the reach of the law, neither will others. Such a compound and mutually reinforcing breach in the rule of law must frustrate the development East Africa sorely needs.

32. Mbaku, supra note 8, 1019.

33. Id. at 1036 .

34. Id. at 1002 .

35. Id. at 1004-05 (footnote omitted). 


\section{HUMAN RIGHTS AND EAST AFRICA}

Part I of this article has presented a general treatment of the rule of law and a brief observation on the special challenges and needs of East Africa regarding the rule of law. Part II similarly will present a general treatment of human rights and then a brief observation on how they stand in East Africa. The parts share unhappy parallels.

The cause of human rights is no less celebrated these days than that of the rule of law. In fact, recent years have seen "the development of human rights as a kind of world religion. ${ }^{" 36}$ Not that human rights are wholly new-fangled:

We hold these Truths to be self-evident, that all Men are created equal, that they are endowed by their Creator with certain unalienable Rights, that among these are Life, Liberty, and the Pursuit of Happiness-That to secure these Rights, Governments are instituted among Men .... ${ }^{37}$

What is new, however, is the breadth of rights now generally thought to be included in the list of human rights, specifically rights that civil government supply basic human needs rather than rights that civil government forbear to injure human beings.

To be sure, the very existence of civil government is to supply a basic human need. The Declaration of Independence says as much. Civil government exists to secure civil justice or, in the words of the Declaration, "to secure" "unalienable Rights." But traditionally, though civil government was to secure rights, no one was understood to have a right that the civil government do so. ${ }^{38}$ Rather, rights as against civil government limited its power as it went about doing justice and securing

36. Richard Stith, If Dorothy had not had Toto to Pull Back the Wizard's Curtain: The Fabrication of Human Rights as a World Religion, 44 VAL. U. L. REV. 847, 850 (2010).

37. The Declaration of IndePendence para. 2 (U.S. 1776); see also Craig A. Stern \& Gregory M. Jones, The Coherence of Natural Inalienable Rights, 76 UMKC L. REV. 939 (2008) (setting forth the longstanding tradition of natural inalienable rights).

38. See, e.g., DeShaney v. Winnebago Cty. Dep't of Soc. Services, 489 U.S. 189, 195-96 (1989). 
rights. Political and legal history account for the development of such rights against the abuses of civil government, with government threats to liberty providing the impetus for the legal recognition of rights to set limits to government power. ${ }^{39}$ Armed with legal rights, the subjects of civil government could enlist the institutions of the law-courts above all-to protect themselves against the all-too-likely trespasses of civil government.

These traditionally recognized rights against improper acts of the civil government are called "negative rights." 40 They are negative because they fundamentally call upon the civil government not to act.

There is a thin and confusing line between government action and inaction, but a negative right is one that can always be satisfied by inaction of some kind (even if it may also alternatively be satisfied by a government action), while a positive right cannot be satisfied by inaction and intrinsically requires government action. ${ }^{41}$

So, for example, rights against the deprivation of life, liberty, or property at the hands of the civil government are negative rights. They specify actions the civil government may not perform. They limit the power of civil government.

Not so the other major category of rights against civil government, the so called "positive rights." 42 "One category [the negative] is a right to be

39. See Frank B. Cross, The Error of Positive Rights, 48 UCLA L. REv. 857, 868 (2001).

40. See id. at 868-74.

41. Id. at 869 (footnote omitted). Elsewhere, Cross "propose[s] the following simple test for distinguishing between positive and negative rights - if there was [sic] no government in existence, would the right be automatically fulfilled?" $I d$. at 866. Notwithstanding, it is possible to see the categories of negative and of positive rights as "blur[ring] at the edges." Helen Hershkoff, Forward: Positive Rights and the Evolution of State Constitutions, 33 RUTGERs L.J. 799, 809 (2002) (proffering supposed examples of such blurring).

42. Positive rights also go by the name of "second-generation" rights, this in distinction from negative "first-generation" rights and from "third-generation" rights to such things as a clean environment and community development. See Abbie Sachs, Social and Economic Rights: Can They Be Made Justiciable?, 53 SMU. L. REV. 1381, 1383-84 (2000). 
free from government, while the other [the positive] is a right to command government action." ${ }^{, 43}$ Positive rights call upon the civil government to supply a need, not simply to avoid an active transgression of its own. Positive rights, therefore, entail a political theory, a vision of the purpose and reach of civil government, whereas negative rights entail only a sense of what constitutes an "affirmative" injury to the person. ${ }^{44}$

Two foundational instruments of the United Nations lend strong support to positive human rights against civil governments. The UN General Assembly adopted the Universal Declaration of Human Rights in $1948 .{ }^{45}$ While not itself legally binding, it embraces both negative and positive rights, like rights to work, fair wages, unions, public assistance, health care, and education. ${ }^{46}$ The other UN instrument, advocated by the Soviet Union and as yet unratified by the United States, embraces such positive rights almost entirely. ${ }^{47}$ This treaty, the International Covenant for Economic, Social and Cultural Rights, ${ }^{48}$ the UN adopted in $1966 .{ }^{49}$

43. Cross, supra note 39 , at 864 . It should be noted at the outset of this discussion of positive rights that contemporary usage of this term departs from the usage of the early (first?) proponent of the similar dichotomy of negative and positive liberty. For Isaiah Berlin, negative liberty meant the freedom from obstruction, while positive liberty meant the freedom to effect one's goals, including in the context of society as a whole. See Matthew Lewans, Rethinking the Diceyan Dialectic, 58 U. Toronto L.J. 75, 78, 91-95 (2008).

44. The political theory supporting positive human rights has been espoused by socialists and Roman Catholic authorities. See Mary Ann Glendon, The Forgotten Crucible: The Latin American Influence on the Universal Human Rights Idea, 16 HARV. Hum. RTs. J. 27 (2003); Wiktor Osiatynski, Social and Economic Rights in a New Constitution for Poland, in Western Rights? Post-Communist Application, supra note 14, at 233, 233, 255. Perhaps the most prominent supporter of positive human rights has been President Franklin D. Roosevelt. See Cross, supra note 39, at 858.

45. Universal Declaration of Human Rights, G.A. Res. 217 (III) A, U.N. Doc. A/RES/217(III) (Dec. 10, 1948); see, e.g., Eric A. Posner, Human Welfare, Not Human Rights, 108 CoLUM. L. ReV. 1758, 1765 (2008).

46. Posner, supra note 45, at 1764-65; Udombana, supra note 31, at 139 ("The UDHR guarantees a full complement of rights - civil and political, as well as economic, social and cultural - and provides that everyone has a right to an effective remedy for violations of these rights.") (footnote omitted).

47. See Posner, supra note 45, at 1764-65.

48. International Covenant on Economic, Social and Cultural Rights, Dec. 16, 1966, 993 U.N.T.S. 3 [hereinafter ICESCR]; see Posner, supra note 45, at 1764.

49. Posner, supra note 45, at 1759 n.7. 
Positive and negative rights against civil government fundamentally differ from each other. At root, this difference rests upon a fundamental difference between the nature of positive and the nature of negative moral duties. Saint John Paul II explained:

In the case of the positive moral precepts, prudence always has the task of verifying that they apply in a specific situation, for example, in view of other duties which may be more important or urgent. But the negative moral precepts, those prohibiting certain concrete actions or kinds of behavior as intrinsically evil, do not allow for any legitimate exception. They do not leave room, in any morally acceptable way, for the "creativity" of any contrary determination whatsoever. Once the moral species of an action prohibited by a universal rule is concretely recognized, the only morally good act is that of obeying the moral law and of refraining from the action which it forbids. ${ }^{50}$

It is typical of negative duties that they may be categorical. It is typical of positive duties that likely they are not. Positive duties call for specifications and qualifications inessential to negative duties.

The situation is similar with positive rights against civil government. So, for example, a right to be employed requires that the state decide who is best suited for any particular position. ${ }^{51}$ Or a right to health care may be guaranteed, but this right is to be situated in the context of given laws and practice, and may be limited by law. ${ }^{52}$ Whereas negative rights may be absolute, positive rights generally are contingent.

[P]ositive rights are typically not just rights to have the state act but rights to have the state act effectively, i.e. rights to a result, such as the provision of water. But the future is always uncertain. Rainfall and climate may vary. Rules for action or inaction, the stuff of ordinary 1993).

50. John Paul II, The SPlendor of Truth $\S 67$, at 87 (Pauline Books \& Media

51. See HAYEK, supra note 5, at 121-22.

52. See Joachim Sanden \& Sascha-Dominik Bachmann, The Right to Liberty and Security, Public Health and Disease Control, speakers at The Congress of the Institute of Advanced Legal Studies: "National Security and Public Health: Exceptions to Human Rights?" (May 29, 2014). 
litigation, can in principle be clear and even absolute, but the means needed to effect results are always tentative and contingent. ${ }^{53}$

This quotation suggests another aspect of the difference between negative and positive rights. Rights typically are enforceable by some tribunal:

$[R]$ ights in the full sense are legal entitlements, not just competing social interests or desires. So only judicial or quasi-judicial authorities (using reasoned elaboration of general norms to decide cases), and not legislatures (representing the will of the people in formulating general norms), are competent to decide the concrete weight to be given each right. ${ }^{54}$

53. Stith, supra note 36, at 857; cf. David S. Law \& Mila Versteeg, Sham Constitutions, 101 CALIF. L. REv. 863, 916 (2013) (observing that poor countries may find it more challenging to fulfill positive rights than negative owing to the costs entailed in the former); Uchechukwu Ngwaba, The "Right to Health" as the Basis for Transforming the Primary Health Care System of Nigeria (Sept. 25, 2013), available at http://ssrn.com/abstract=2440419 (noting the aspirational and precatory nature of rights to health); Osiatynski, supra note 44, at 242-43 (explaining the inherent political contingency of positive social and economic rights); Elizabeth Pascal, Welfare Rights in State Constitutions, 39 RUTGERS L.J. 863, 866-67 (2008) (explaining the inherent political contingency of positive social and economic rights); Ulrich K. Preuss, The Conceptual Difficulties of Welfare Rights, in Western Rights? POST-COMMUNIST APPLiCATION, supra note 14, at 211, 211 ("[M] ost positive rights are different [from negative rights] in that their enforcement calls for government actions with are not fully determined by those rights, which are subject to policy choices, amenable to criteria of expediency and exposed to public debate."). Certainly, there can exist against civil government positive rights that minimize this tentativeness and contingency. Think, for example, of a right that each citizen receive one dollar from the government every month. At least until the money runs out, fulfilling this right involves little tentativeness and contingency. The focus of this article, however, is positive rights of a very different sort: the sort of general rights to health, education, and welfare to be found in the international, constitutional, and statutory law of the nations of East Africa.

54. Stith, supra note 36 , at 856 . Another way of stating the first sentence of this quotation is, "Rights are peremptory. . . . [So a right to a social security payment, for example, means] that the government shall send this payment ..., period. No questions asked. It is not to send the payment ... when the government believes ... that it would serve the greater good to do so or the good of the recipients. It is to send the payment, period." Nicholas WolterstorfF, Justice: RightS AND WrongS 291-92 (2008). 
In this context, general negative rights are "rights in the full sense." But general positive rights are not so. They are called rights, but they likely receive no enforcement at law. ${ }^{55}$ Negative and positive rights against civil government, then, differ in fundamental respects.

The difference between negative and positive rights appears in a comparison of the International Covenant on Civil and Political Rights ("ICCPR") ${ }^{56}$ with the International Covenant on Economic, Social and Cultural Rights ("ICESCR"). ${ }^{57}$ These two covenants, twin offspring of the Universal Declaration of Human Rights, ${ }^{58}$ largely fall on opposite sides of the divide between negative and positive rights. The ICCPR does require states parties to provide remedies, ${ }^{59}$ to outlaw slavery and forced labor, ${ }^{60}$ to protect everyone against certain interference or attacks by third parties, ${ }^{61}$ and to protect children generally, ${ }^{62}$ thereby seeming to secure positive rights against states parties. Nevertheless, it largely is

55. See, e.g., A.E. Dick Howard, The Indeterminacy of Constitutions, 31 WAKE FOREST L. REV. 383, 408-09 (1996) (observing that positive constitutional rights are not for judicial enforcement); Preuss, supra note 53, at 211 (“[T] he courts are not competent actors for [the] enforcement [of positive rights].”); Sanden \& Bachmann, supra note 52 (noting that the German constitutional rights to protection against others is not as much legal as it is a call for protective legislation). Here lies an important distinction between a right and its remedy. A positive right might entail a negative remedy: the denial of a right to receive a dollar might be remedied by an order prohibiting the payer from striking the complainant from the list of payees. Likewise, a negative right might entail a positive remedy: the denial of the right not to be injured physically might be remedied by an order requiring the payment of damages. The point to be made, however, is that positive rights typically lack the categorical certainty of negative rights, whatever remedies might come into play.

56. International Covenant on Civil and Political Rights, Dec. 16, 1966, 999 U.N.T.S. 171 [hereinafter ICCPR].

57. See ICESCR, supra note 48.

58. See Posner, supra note 45, at 1765; Craig Scott \& Patrick Macklem, Constitutional Ropes of Sand or Justiciable Guarantees? Social Rights in a New South African Constitution, 141 U. PA. L. REV. 1, 89-90 (1992) (attributing the twinning in part to the circumstance that "social [i.e., positive] rights were not viewed as justiciable because courts, or court-like bodies, were not thought to be competent bodies to deal with them").

59. ICCPR, supra note 56, art. 2, para. 3(a).

60. Id. art. 8. para. 1, 3(a).

61. Id. art. 17, para. 2 .

62. Id. art. 24. 
dedicated to securing the classic negative rights such as those against state deprivation of life, ${ }^{63}$ state imposition of torture or degrading treatment, ${ }^{64}$ state violation of liberty and personal security, ${ }^{65}$ state misuse of incarceration, ${ }^{66}$ state failure to adhere to fundamental procedural standards in administering justice, ${ }^{67}$ and state abridgement of religion, ${ }^{68}$ of freedom of expression, ${ }^{69}$ of assembly, ${ }^{70}$ and of association. ${ }^{71}$ While the ICCPR expressly qualifies a few of these rights, ${ }^{72}$ others it expressly makes non-derogable. ${ }^{73}$

Compare with the ICCPR the ICESCR. The latter requires states parties to secure a broad range of positive rights, ${ }^{74}$ such as those related to work, ${ }^{75}$ to social security, ${ }^{76}$ to an adequate and ever improving standard of living, ${ }^{77}$ to health, ${ }^{78}$ to education, ${ }^{79}$ and to benefitting from culture and scientific progress. ${ }^{80}$ But unlike the ICCPR with its limited qualifications and its set of non-derogable rights, ${ }^{81}$ the ICESCR makes no rights non-derogable and, to the contrary, emphasizes the general contingency of all the rights it secures:

63. Id. art. 6.

64. Id. art. 7.

65. Id. art. 9.

66. See id. art. 10, 11.

67. See id. art. 14, 15, 16.

68. Id. art. 18.

69. Id. art. 19.

70. Id. art. 21.

71. Id. art. 22.

72. See id. art. 14, 21, 22.

73. Id. art. 4, para. 2.

74. In some cases it is difficult to tell whether the ICESCR frames rights as positive or negative. See, e.g., ICESCR, supra note 48, art. 6, para. 1; art. 7, 15. This very difficulty only exacerbates the uncertainty and contingency of these rights that may carry a positive component.

75. See id. art. 6, 7 .

76. Id. art. 9 .

77. Id. art. 11 .

78. Id. art. 12 .

79. Id. art. 13 .

80. Id. art. 15 .

81. See supra notes $72-73$ and accompanying text. 
Each State Party to the present Covenant undertakes to take steps, individually and through international assistance and co-operation, especially economic and technical, to the maximum of its available resources, with a view to achieving progressively the full realization of the rights recognized in the present Covenant by all appropriate means, including particularly the adoption of legislative measures. ${ }^{82}$

Developing countries, with due regard to human rights and their national economy, may determine to what extent they would guarantee the economic rights recognized in the present Covenant to nonnationals. $^{83}$

The States Parties to the present Covenant recognize that, in the enjoyment of those rights provided by the State in conformity with the present Covenant, the State may subject such rights only to such limitations as are determined by law only in so far [sic] as this may be compatible with the nature of these rights and solely for the purpose of promoting the general welfare in a democratic society. ${ }^{84}$

82. See ICESCR, supra note 48, art. 2, para. 1 (emphasis added).

83. Id. para. 3 (emphasis added).

84. Id. art. 4 (emphasis added). In addition, as to "the right of everyone to education," $i d$. art. 13, para. 1, and specifically the guarantee that "[p]rimary education shall be compulsory and available free to all," $i d$. para. 2.a, the Covenant provides:

Each State Party to the present Covenant which, at the time of becoming a Party, has not been able to secure in its metropolitan territory or other territories under its jurisdiction compulsory primary education, free of charge, undertakes, within two years to work out and adopt a detailed plan of action for the progressive implementation, within a reasonable number of years, to be fixed in the plan, of the principle of compulsory education free of charge for all.

Id. art. 14 (emphasis added). Compare with this provision the explanation the United Nations Committee on Economic, Social, and Cultural Rights offers regarding the obligation imposed by article 2, paragraph 1: "In interpreting States' obligations under Article 2(1) of the ICESCR, the ESC Committee states that, though a State need not achieve the full realization of socioeconomic rights immediately, it has an immediate duty to construct a program or action plan towards their realization." Udombana, supra note 31, at 167 (footnote omitted). 
Such a marked difference between the ICESCR and the ICCPR leaves little doubt of the fundamental distinction between negative and positive rights, and especially their quality as categorical or contingent.

Positive and negative rights are so distinct that there ought to be doubt whether positive rights should share the celebrity of negative rights. ${ }^{85}$ Positive rights tend to be ineffective. ${ }^{86}$ On the other hand, if actually fully implemented, they could work a radical social revolution that one suspects would lack genuine and widespread support. ${ }^{87}$ Qualities such as these may justly raise the question whether positive rights are worth the stating. Perhaps more importantly, to provide for positive rights may well put negative rights at risk. If some rights are contingent, strictly unenforceable, and have the effect more of marking an interest than of setting forth a rule of law, perhaps all rights will be taken to do the same. Even if the law distinguishes positive rights from negative in an attempt to isolate the categories from each other, nevertheless, both categories comprise rights. Rights, therefore, do not inherently establish rules of law. They do not grant or secure protection safe from pragmatic balancing and economizing. "In short, the inclusion of enforceable positive rights in constitutions may destroy negative rights." 88

85. "In fact, no country places social rights in the same category as political or civil rights - the so-called negative rights." Pascal, supra note 53, at 865.

86. See Law \& Versteeg, supra note 53, at 871 ("With respect to socioeconomic and group rights in particular, more rights on paper is associated with less respect for rights in practice."). "Our findings are modestly consistent with the view that positive rights are harder to uphold, and thus more likely to be violated, than negative rights." Id. at 916. Cass R. Sunstein, Against Positive Rights, in Western Rights? PostCOMMUNist APPLiCATION, supra note 14, at 225, 225 (arguing against positive constitutional rights as futile and dangerous).

87. See, e.g., Special Rapporteur on Extreme Poverty and Human Rights, Promotion and Protection of Human Rights: Human Rights, transmitted by Note of the Secretary-General, U.N. Doc. A/68/293 (Aug. 9, 2013).

88. Osiatynski, supra note 44, at 254. See also C. Scott Pryor, Looking for Bedrock: Accounting for Human Rights in Classical Liberalism, Modern Secularism, and the Christian Tradition, 33 CAMPBELL L. REv. 609, 620 (2011) ("[O]nce a political system permits limits on the exercise of human rights by the political process, the risk of reducing rights to only one factor among many in a utilitarian calculus will quickly become a reality.") (footnote omitted); Sunstein, supra note 86, at 225: 
As with the rule of law, the East African context for human rights presents special challenges. Constitutional provisions announcing protection for human rights - including positive human rights - may sweep broad indeed. ${ }^{89}$ At the same time, actual protection may be weak,

If we look at the actual and proposed constitutions for Eastern Europe, we will find a truly dazzling array of social and economic rights. The Hungarian Constitution, for example, protects not merely the right to equal pay for equal work, but also the right to an income conforming with the quantity and quality of work performed. (Pause for a moment over what it would mean for the Hungarian Constitutional Court to take these provisions seriously). The Slovak Constitution right to a standard of living commensurate to each citizen's potential and that of society as a whole [sic]. It also includes the right to just pay. Almost all of the actual document and proposed drafts include the rights to recreation, to paid holidays, to food and shelter, to a minimum wage, and to much more. A chaotic catalogue of abstractions from the social welfare state coexists with the traditional rights to private property, free speech, and so no.

I think that this is a large mistake, possibly a disaster. It seems clear that Eastern Europe countries should use their constitutions principally to produce two things: (i) firm liberal rights-free speech, voting rights, protection against abuse of the criminal justice system, religious liberty, protection from and prevention of invidious discrimination, property and contract rights; (ii) and the preconditions for some kind of market economy. The endless catalogue of what I will be calling "positive rights," many of them absurd, threatens to undermine both of these important tasks.

89. See, e.g., Smith Otieno, Transformative Constitutionalism: Contextualizing Human Rights Application under the Constitution of Kenya 2010 17, (Dec. 15, 2014) (unpublished manuscript), available at $\mathrm{http}: / / \mathrm{ssrn} . \mathrm{com} / \mathrm{abstract}=2439158$. The African Charter on Human and Peoples' Rights, subscribed by all the nations of East Africa but for South Sudan, broadly secures both negative and positive rights, and that without distinction or qualification. So the right to liberty, property, and religion are secured along with the rights to work, health, and education on equal terms. African Charter on Human and People's Rights, OAU Doc. CAB/LEG/67/3, art. 6, 8, 14, 15, 17, 18 (Jun. 27, 1981). "The Charter guarantees all categories of human rights equally." Udombana, supra note 31, at 143. Again, it seems impossible that such equality would not reduce the protection of negative rights to that necessarily suited to positive, with consequences for the rule of law not difficult to predict. That South Sudan has not yet agreed to the Charter does not indicate its dislike of general positive rights. For example, its constitution 
especially for positive human rights. ${ }^{90}$ In South Sudan, for example, a generous bill of rights appealing to Western constituencies stands alongside a constitution with structural provisions that establish a dominating national executive power equipped with prerogative more than enough to compromise any rights. ${ }^{91}$ It may well be true of East African civil governments that an inability to provide the services promised by positive rights leads to the formal government affirmation of those very positive rights:

\begin{abstract}
Already ashamed at being poor and backward, a state may sense that it may never have the means fully to supply all positive rights, or even just the right to water. Such a government may seek to prove its sincere intentions by abject apologies and repeated confessions of absolute faith in human rights, and wholesale surrender to the demands of the authorities claiming to articulate those rights. ${ }^{92}$
\end{abstract}

Furthermore, the fear that providing positive rights might harm the protection of negative rights sadly may be well warranted in East Africa. The push for development in Africa has led its proponents to advance the claim of positive rights at the expense of negative rights, rights portrayed as "bourgeois" and costly to the masses, impeding the development desperately required for the public good. ${ }^{93}$ The state of human rights in East Africa appears none too good, no thanks to the inclusion of positive

provides, "Every citizen has the right to have access to decent housing." TRANSITIONAL Constitution of the Republic of South Sudan [Constitution] July 9, 2011, art. 34 § 1 (South Sudan).

90. See Law \& Versteeg, supra note 53, at 906.

91. See Kevin L. Cope, South Sudan's Dualistic Constitution, in The Social AND Political Foundations of Constitutions 295 (D.J. Galligan \& Mila Versteeg eds.) (2013).

92. Stith, supra note 36, at 860.

93. See H. Kwasi Prempeh, Marbury in Africa: Judicial Review and the Challenge of Constitutionalism in Contemporary Africa, 80 TUL. L. REV. 1239, 1267 (2006); cf. Frank B. Cross, International Determinants of Human Rights and Welfare: Law, Wealth, or Culture, 7 IND. INT'L \& CoMP. L. REV. 265, 266 (1997) (“Some suggest that the law's devotion to the protection of negative human rights might actually undermine human welfare."). 
rights among those finding support on paper but lacking support much beyond that.

\section{EAST AFRICA, HUMAN RIGHTS, AND THE RULE OF LAW}

As we have seen, the civil governments of East Africa face daunting challenges as they aspire to secure both the rule of law and a wide range of human rights. Each of these aspirations brings with it challenges of its own. More daunting still, however, are the challenges owing to the tension between these aspirations. The very commitment to securing a wide range of human rights contributes to the difficulty of securing the rule of law.

Among the rights civil governments in East Africa pledge themselves to secure are broad positive rights, rights that oblige the governments by law to supply such goods as health, education, employment, and housing. ${ }^{94}$ The contingencies and qualifications entailed in these rights distinguish them from negative rights and yet, as explained above, at the same time may present a threat to negative rights. ${ }^{95}$ These factors likewise present a threat to the rule of law.

One way to understand the threat positive rights present to the rule of law rests upon the fact, already noted, ${ }^{96}$ that positive, unlike negative rights, ${ }^{97}$ typically embody guaranteed results and not simply rules proscribing or prescribing acts. Positive rights broadly are "consequentialist," and therefore "highly indeterminate." 98 These qualities make positive rights generally unsuited to judicial resolution, ${ }^{99}$

94. See supra notes 89-92 and accompanying text.

95. See supra notes 51-88 and accompanying text.

96. See supra note 53 and accompanying text.

97. "One potential source of human rights and welfare is the prominence of the rule of law. The potential significance of law is most apparent with respect to the classical negative human rights, because such rights are legally defined and legally enforced against an infringing government." Cross, supra note 93, at 265.

98. Cross, supra note 39, at 901; see also Kathleen G. Noonan, Charles F. Sabel \& William J. Simon, Legal Accountability in the Service-Based Welfare State: Lessons from Child Welfare Reform, 34 LAW \& Soc. INQUIRY 523, 560-62 (2009); Preuss, supra note 53 , at 211.

99. The whole of the Cross article, The Error of Positive Rights, argues, as its abstract concludes, "Should positive rights be given effect, there is a serious chance that 
and often the very formulation of positive rights provides that courts not be the organ of civil government to enforce them. ${ }^{100}$ Lon Fuller captured the principle: "it may be said that problems in the allocation of economic resources present too strong a polycentric aspect to be suitable for

judicial intervention and enforcement of them could actually have counterproductive effects." Cross, supra note 39, at 857 (emphasis omitted). See Nsongurua J. Udombana, Social Rights Are Human Rights: Actualizing the Rights to Work and Social Security in Africa, 39 CORNELL INT'L L.J. 181, 209 n.258 (2006) (providing sources which debate the justiciability of social (positive) rights.). Many suggest that positive rights are to be enforced ultimately by legislative, rather than judicial, action. See, e.g., Jonathan Feldman, Separation of Powers and Judicial Review of Positive Rights Claims: The Role of State Courts in an Era of Positive Government, 24 RUTGERS L.J. 1057, 1061-63, 1085, 1091 (1993); Helen Hershkoff, Welfare Devolution and State Constitutions, 67 FordHAM L. ReV. 1403, 1414, 1430 (1999); Pascal, supra note 53, at 882, 884, 887; Mark Tushnet, Social Welfare Rights and the Forms of Judicial Review, 82 TEX. L. REV. 1895, 1901-02 (2004). In Keeping the Promise, Udombana opined, "There is no concrete evidence that judicial forays into the fields of socioeconomic [i.e., positive] rights have led to immediate realization of these rights, but a sustained and creative interpretation of constitutionally guaranteed rights will have a positive impact on State's behavior over time." Udombana, supra note 31, at 178 (footnote omitted). Scott \& Macklem assert, "If [positive social rights are] expressly phrased as rights, even if nonjusticiable, individual circumstances would command greater attention in politics and policymaking as long as political institutions are structured or simply function in such a way that takes constitutional commitments seriously." Scott \& Macklem, supra note 58, at 40. They also assert that "the constitutionalization of social rights will place the judiciary in a new and unfamiliar environment. Social rights require the judiciary to explicitly adopt a promotional and creative stance .... [and] 'to accept the realities of a changed conception of law ....'" Id. at 84. Perhaps by this they mean that "[c]ourts [are to] be vested with the role of prodding other branches [of civil government] in the event of unreasonable failures to act or in cases of inadequate action." Id. at 134. Similarly, a justice of the Constitutional Court of South Africa has suggested that constitutional positive rights may serve not "as a justiciable part of a bill of rights, but as directives of state policy," Sachs, supra note 42, at 1384 (describing the situation in Ireland), or as providing the opportunity for a court to "declare that the [political branches] are in dereliction of constitutional obligation." Id. at 1390 (describing his own South Africa). The universal consensus in any event seems to be that general positive rights are not justiciable after the usual fashion. After proposing, analyzing, and applying a subtle grid for understanding positive rights, distinguishing weak and strong rights and, separately, weak and strong remedies, Tushnet concludes, "Yet, in the end, maintaining the credibility of both courts and constitutions that contain social welfare rights might require that social welfare rights be nonjusticiable.” Tushnet, supra note 99, at 1919.

100. See supra note 53 and accompanying text. 
adjudication," 101 using "polycentric" to refer to a complex problem, the resolution of which has complex repercussions, all interrelated much like the strands of a spider web. ${ }^{102}$ Instead of adjudication, legislation or administration are the proper tools to be used by civil government to resolve polycentric problems. ${ }^{103}$

Fuller's discussion of polycentricity has still more to offer for the present discussion. Even if the sources creating positive rights against civil government recognize that such rights ought not to be enforced by courts, labeling the interests they create "rights" presents a distinct problem.

A right is a demand founded on a principle - a principle regarded as appropriately controlling the relations of two parties. Now it is characteristic of a polycentric relationship that the relations of individual members to one another are not controlled by principles peculiar to those relations, just as it is impossible to build a bridge by establishing distinct principles governing the angle of every pair of girders. So in a baseball team, no one has a "right" to left field, or at least, no one ought to. ${ }^{104}$

And so the problem comes with casting positive rights as "rights," whether for courts or for other governmental institutions. For the law to label positive rights "rights" at all, causes rights to become something less than categorical expressions of a legal relation. It degrades rights into interests.

Beyond this effect, however, if rights become interests what consequences follow for the rule of law? (Indeed, what consequences follow for law itself if rights, the creation of rules of law, become interests? What becomes of rules if they sketch interests instead of fixing rights?)

Whether or not positive rights are for courts to enforce or instead become the business of some other institution of civil government,

101. Lon L. Fuller, The Forms and Limits of Adjudication, 92 HARV. L. REV. 353, 400 (1978).

102. Id. at 394-405.

103. See id. at $398-400$.

104. Id. at 404 . 
creating positive rights affects the health of the rule of law. For one thing, keeping the enforcement of positive rights from the courts does not automatically insulate the rule of law from the effects of positive rights. How the administrative state - the alternative enforcer of positive rights - possibly may preserve the rule of law is a vexing question. ${ }^{105}$ Also vexing is the question whether any state given to securing positive rights may exist within the framework of the rule of law.

The rule of law demands that the law fundamentally comprise rules. ${ }^{106}$ The question arises, then, whether a civil government can secure broad positive rights within a system of rules. ${ }^{107}$ In words regarding general economic planning by civil government, but precisely appropriate to supplying general positive rights, Hayek wrote:

The planning authority cannot confine itself to providing opportunities for unknown people to make whatever use of them they like. It cannot tie itself down in advance to general and formal rules which prevent arbitrariness. It must provide for the actual needs of people as they arise and then choose deliberately between them. It must constantly decide questions which cannot be answered by formal principles only, and, in making these decisions, it must set up distinctions of merit between the needs of different people. ${ }^{108}$

105. See, e.g., Roberto M. Unger, LAw In Modern Society (1976); Epstein, supra note 8, at 78. But see Lewans, supra note 43 (tracing Dicey's classic criticism of administrative law more to his political theory than to necessary principles of the rule of law).

106. See supra notes 5-7 and accompanying text; see also Antonin Scalia, The Rule of Law as a Law of Rules, 56 U. CHI. L. REV. 1175 (1989).

107. If the rule of law operates effectively only under the vigilance of the ruled, there is at least one other question on the compatibility of positive rights with the rule of law: "[T] here is a danger that the man in the street still comes to look at the state-source of so many of his most valued expectations - with a new affection that undermines the healthy suspicion with which the sturdy citizen of a free society should regard officialdom and all its works." Jones, supra note 9, at 146.

108. HAYEK, supra note 5, at 113. 
Positive rights guarantee results. ${ }^{109}$ Guaranteeing results resists reduction to rules of action. ${ }^{110}$ "[P] rovid[ing] for the actual needs of people as they arise" $" 111$ seems an intractable challenge for a regime of rules.

The typical qualifications placed upon positive rights exacerbate this challenge. Here again the words of Hayek regarding the planned economy are no less appropriate for positive rights against civil government:

[I]t becomes regularly necessary to qualify legal provisions increasingly by reference to what is "fair" or "reasonable"; this means that it becomes necessary to leave the decision of the concrete case more and more to the discretion of the judge or authority in question. One could write a history of the decline of the Rule of Law . . . in terms of the progressive introduction of these vague formulas into legislation and jurisdiction, and of the increasing arbitrariness and uncertainty of, and the consequent disrespect for, the law and the judicature .... ${ }^{112}$

Positive rights become matters of degree, and matters of degree are not the stuff of rules. Broad positive rights also demand the balancing of rights or even fundamental principles, an enterprise, if constitutionalized, sure to yield indeterminacy. ${ }^{113}$ Such balancing compounds the difficulty of subjecting the matter to governance by rules and, consequently, to the rule of law.

Difficulties like these have led in some cases to reformulating positive rights against civil governments. ${ }^{114}$ Instead of guaranteeing results - the

109. See supra note 53 and accompanying text.

110. Id.

111. See supra text accompanying note 108 .

112. HayeK, supra note 5, at 116. See also F.A. HayeK, The Constitution of LIBERTY 231-32, 257-61 (1960); HAYEK, supra note 5, at 113-21. Hayek's fears that for civil government to supply the goods secured by positive rights would doom the rule of law did not go unanswered for long. See, e.g., Jones, supra note 9 (discussing how the rule of law might best be preserved in such circumstances). More recent scholarship, however, has supported Hayek's view. See, e.g., Noonan, Sabel \& Simon, supra note 98; Preuss, supra note 53, at 219.

113. See, e.g., Howard, supra note 55, at 402.

114. Hershkoff opines that the enforcement of positive rights has enjoyed some measure of success, pointing out their "constitutive effect" and "expressive and solidarity value." Hershkoff, supra note 41, at 828-30. 
actual provision of education, health care, and housing, for examplepositive rights have been transformed into something less, something thought to be less threatening to the rule of law. ${ }^{115}$ So, a duty to implement positive rights becomes a duty only to make progress towards implementing them. ${ }^{116}$ Or the duty may be considered one only to provide process to the holders of positive rights. ${ }^{117}$ Such cures likely bring their own threats to the rule of law. To transform a right to something into a right that the civil government only make some progress towards providing that something transforms a right into an aspiration that resists rules. What test may the law apply to determine

115. Cf. Fuller, supra note 101, at 401 (noting the transformation of polycentric problems into problems more susceptible of adjudication). For example, the Constitution of South Sudan states, "The elderly and persons with special needs shall have the right to the respect of their dignity. They shall be provided with the necessary care and medical services as shall be regulated by law." ConstiTuTION 2011, art. 30, § 2 (South Sudan) (emphasis added). In one sentence, the promise of care and medical services that are necessary becomes instead care and medical services that the law happens to provide. And sometimes purported positive rights turn out actually to be negative rights of the stripe frequently enforced by the courts. See, e.g., Constitution 2011, art. 34 (South Sudan); Constitution 2005, art. 45 (Sudan); Pascal, supra note 53, at 872-73 (describing how an equal protection interpretation of positive rights turns them into negative rights); Scott \& Macklem, supra note 58, at 61-62, 74, 78 (parading negative rights as positive "social" rights); Udombana, supra note 31, at 180, 183.

116. See, e.g., Law \& Versteeg, supra note 53, at 916 n.143; Pascal, supra note 53, at 890,892 (describing use of the "reasonableness" standard and of "programmatic rights"); Sachs, supra note 42, at 1385, 1389; Scott \& Macklem, supra note 58, at 75-81, 134, 147-48 (suggesting courts not dictate the means of fulfilling positive rights but rather, by providing a forum "for telling . . . stories" and for discourse, promote progress towards their fulfillment); Tushnet, supra note 99, at 1910-11. More than one commentator has suggested that a celebrated South African case adopting the progressive approach "did little to change the status quo in South Africa with regard to a right to basic shelter," the right at issue in that case. Rosalind Dixon, Creating Dialogue About Socioeconomic Rights: Strong-Form Versus Weak-Form Judicial Review Revisited, 5 INT'L J. CONST. L. 391, 392 (2007).

117. See, e.g., Muchesia v. Muchesia, (2014) K.L.R. (Kenya) (converting the constitutional right to a clean and healthy environment into a right to have a mill licensed before construction); Noonan, Sabel \& Simon, supra note 98, at 561; Sachs, supra note 42, at 1385-86 (describing the right to medical care as the right to wait in a line to receive medical care); Scott \& Macklem, supra note 58, at 82 (describing the right to food as a right to have the civil government engage in such conduct as performing studies, making plans, ensuring popular participation, and monitoring). 
when such a right is violated? The situation is the same with transforming a right to an object into a right only to receive some government process regarding what was to be the object of the right. This move proffers a new right, itself not governed by rules, and so undercuts the very process right into which the original right has been transformed. These measures, again, not only deflate the concept of rights generally; they also present no remedy for the tension between positive rights and the rule of law.

The tension between the grant of positive rights against civil government and subjecting civil government to the rule of law is also something of an irony. Presumably, rendering the welfare objectives of government into rights - and rights documented in formal legal instruments - is to elevate those objectives into legal duties. It is to lock the government in, as it were, to following through. The civil government itself becomes a lawbreaker should it not satisfy those rights. Positive rights take advantage of the dignity, the certainty, the authority of law to secure themselves against the vagaries of politics. As we have seen, however, transforming welfare objectives into positive rights has the effect more of deflating law than of elevating positive rights. ${ }^{118}$ Positive rights thrust into the law a salient for turning law into nothing

118. See Osiatynski, supra note 44, at 246 n.20; Sunstein, supra note 86, at 229, 232. Deflating law would seem all the more likely when general positive rights are stated categorically and without qualification, as for example in 2003 CONSTITUTION May 26, 2003, art. 37 (Rwanda) (Choice of Employment, Equal Pay/Work); ConstituTion Aug. 1, 2012, art. 25 (Som.) (Right to Safe Environment); id. art. 27 (Right to Clean and Potable Water, Right to Health Care, Right to Full Social Security); id. art. 30 (Right to Free Education); id. art. 31 (Language and Culture); Constitution 2011, art. 29, 30, 33 (South Sudan) (Right to Education, Right of Persons with Special Needs and the Elderly, Rights of Ethnic and Cultural Communities); Constitution 2005, art. 11, 44 (Sudan) (Environmental \& Natural Resources, Right to Education); ConstiTuTiON 1977, art. 40, 41 (Tanzania) (Clean Environment, Education and Learning). ConstituTion 1995, art. 30, 33, 39 (Uganda) (Right to an Education, Rights of Women, Right to a Clean and Healthy Environment). Compounding the pressure arising from categorical and unqualified statements of general positive rights to deflate law are the almost certain existence of contradictory government directives involving positive rights. For example, compare Constitution 1995, art. 39 (Uganda) (Right to a Clean and Healthy Environment) with id., National Objectives and Directive Principles of State Policy, $\S \S$ IX, XI, XIV (Right to Development, Role of the State in Development, General Social \& Economic Objectives). 
but politics. The rule of law loses all meaning when the law that rules is simply politics. Consequently, political elites may be all too willing to see positive rights secured with all the dignity that law can supply. Law thereby becomes a matter of negotiation, of balancing, of flexible aspiration - the very thing to make the rule of law impossible and their own power secure. If positive rights themselves are introduced into the very definition of the rule of law, ${ }^{119}$ political power will have gained complete victory, for the concept of the rule of law itself will contain its own neutralizing element. How can a regime be taken to task for violating the rule of law when the rule of law itself requires the grant of positive rights necessarily at odds with the core of the rule of law?

Considerations like these heighten the general incompatibility of positive rights and the rule of law in East Africa. Political corruption is widespread in East Africa. ${ }^{120}$ Countries there rich in natural resources suffer from the "resource curse," with government driven more by the acquisition of wealth than anything else, ${ }^{121}$ least of all sound administration under the rule of law. The diversity of people within national borders compounds this problem. "[I]t is often said that politics in many sub-Saharan African countries is essentially an inter-ethnic battle for control of the state motivated by the fact that control of the state apparatus creates the opportunity to transfer wealth from one group to another." 122 Violation of human rights is just one symptom of the consequent failure of civil government. ${ }^{123}$ The rule of law depends

119. See supra notes 21-22 and accompanying text.

120. See supra notes 30-32 and accompanying text.

121. See Davis \& Trebilcock, supra note 5, at 925.

122. Id. at 926 (footnote omitted).

123. See, e.g., Mbaku, supra note 8, at 1028, Otieno, supra note 89, at 7; Prempeh, supra note 93, at 1286-87. Other symptoms are "repression and extraction, massive corruption, administrative bureaucracy, enormous waste, clientelism, institutional collapse, poor policy performance, debt and infrastructure crisis." Udombana, supra note 99, at 231 (footnote omitted). 
heavily on the commitment of governing elites to being ruled by law. ${ }^{124}$ That commitment seems largely to be missing from East Africa. ${ }^{125}$

For the health of the rule of law along with human rights, still more fundamental than the character of political leadership in East Africa is the culture of East Africa.

For the rule of law to exist, people must believe in and be committed to the rule of law. They must take it for granted as a necessary and proper aspect of their society. This attitude is not itself a legal rule. It amounts to a shared cultural belief. . . .

When this cultural belief is not pervasive, the rule of law will be weak or nonexistent.

Cultural beliefs are not subject to complete human control, so it is no easy matter to inculcate belief in the rule of law when it does not already exist. In many societies, the government is distrusted and recourse to the law is feared or avoided. Negative views toward the law are common where the law has a history of enforcing colonial or authoritarian rule, where legal officials are perceived to be corrupt or inept, where legal professionals are distrusted, or where the content or application of the law is seen to be unfair or identified with particular interests or groups within society or within the elite.

A widely shared cultural belief that the law should rule is the essential element of the rule of law-and that is the hardest to achieve. $^{126}$

In this passage, Tamanaha has explained deep-rooted cultural impediments to the rule of law, impediments well ensconced in East

124. See Carothers, supra note 10, at 96, 100; Davis \& Trebilcock, supra note 5, at 923.

125. For this reason, in part, some have insisted on the need for foreign impetus to drive rule of law reform. See Daniels \& Trebilcock, supra note 3, at 131.

126. Tamanaha, supra note 7, at 246-47; see also Brooks, supra note 11, at 2285, 2298, 2301, 2322; Davis \& Trebilcock, supra note 5, at 927-32; Mbaku, supra note 8, at 988. 
Africa. ${ }^{127}$ Of no help whatsoever in this situation is the deleterious complication brought by positive rights, with the further strain it places on the rule of law, especially where the positive rights drive a deeper wedge between the law and the actual acts of civil government. ${ }^{128}$

In fact, for East African civil governments to grant broad positive human rights may be the move precisely contrary to securing the rule of law. Granting such rights is likely "only [to] provide a veneer of legitimacy,"129 distracting attention from the "structural constitutionalism" that East Africa needs, ${ }^{130}$ and that in fact would bolster the rule of law. A corrupt political elite, unchallenged by an effective political dissent, could hide under such a veneer while taking advantage of the very weakening of the rule of law that the grant of positive rights produces. This move could only exacerbate the corruption that itself also undermines the rule of law. At the same time, such a situation further increases the power of those elites, entrenching all the more the forces opposed to the rule of law. All this, in cultures given to adulating political leaders and entrusting them with vast power. ${ }^{131}$ East Africa, then, is positioned to suffer most from the unhappy effects upon the rule of law that positive human rights against civil government brings. ${ }^{132}$

127. See, e.g., Kristen A. Dauphinais, Training a Countervailing Elite: The Necessity of an Effective Lawyering Skills Pedagogy for a Sustainable Rule of Law Revival in East Africa, 85 N.D. L. REV. 53 (2009) (surveying challenges to the rule of law in East Africa with an eye toward improving legal education).

128. The unsettling contradiction between, on the one hand, the distrust of a civil government and, on the other, the reliance upon that government for fulfilling positive rights has not gone unnoticed. See Osiatynski, supra note 44, at 251 n.36.

129. David Luban, Human Rights Pragmatism and Human Dignity, in Philosophical Foundations of Human Rights 263, 12 (Rowan Cruft, S. Matthew Liao \& Massimo Renzo, eds. 2015) (writing specifically of "[a] hollow and toothless system of [international legal human rights]").

130. Prempeh, supra note 93, at 1244.

131. See id. at 1260-68. "African politics breed [sic] personality cults, which are aided by a vast patronage network, especially in rent-seeking States that are already suffering from the resource curse." Udombana, supra note 31, at 164.

132. The systems of customary law in East Africa further reinforce the mutually corrosive relation between the rule of law and positive rights against civil government. Customary law is an effective system. See Brian Z. Tamanaha, A Bifurcated Theory of 


\section{CONCLUSION}

The broad conception of human rights is at odds with the rule of law, and nowhere more than in East Africa. But that East Africa should play host to this unhealthy competition is not wholly of its own design. The impetus behind adopting the sweeping conception of human rights that includes broad positive rights against civil government comes from outside. ${ }^{133}$ To appeal to an international audience, East African countries have gone beyond recognizing the fundamental negative human rights against government lawlessness and have enshrined the full panoply of positive rights. ${ }^{134}$ This move has put both negative rights and the rule of law at risk. ${ }^{135}$

Positive rights against civil government, if not wholly a new development, ${ }^{136}$ are by and large newly hatched creatures of the developed world. ${ }^{137}$ While perhaps positive rights might in some sense be honored by wealthier countries, ${ }^{138}$ less wealthy countries like those of East Africa will find in positive rights no benign measure. Howard, while explaining the international dynamic that leads countries to transplant such foreign elements into their own domestic law, ${ }^{139}$ notes that transplanting "a [legal] proposition in a different cultural, historical, or

Law in Hybrid Societies, in Non-State Justice Institutions and the Law: DecisionMaking at the Interface of Tradition, Religion, and the State 1, 3-4 (M. Koetter et al. eds., 2015) (mentioning South Sudan). Its own departure from the rule of law may not necessarily bode ill. $I d$. at 5-6, 12-16. But its availability as a good alternative to state law for the resolution of some disputes must contribute to the further alienation of the people from state law, undermining the commitment required for state law to adhere to the rule of law. See supra notes 35, 127 and accompanying text. Additionally, the less state law adheres to the rule of law, the more customary law will provide a substitute, feeding the cycle that weakens the rule of law. Formal positive rights are creatures of state law, not customary law. Consequently, the ill effects of positive rights on the legal system remain focused on state law, leaving customary law alone to provide an effective legal system free of the unlawful effects of formal positive rights.

133. See supra notes 91-92 and accompanying text.

134. See supra Part II.

135. See supra Part III.

136. See Cross, supra note 39 , at 872 n.68.

137. See supra notes $36-49$ and accompanying text.

138. See Law \& Versteeg, supra note 53, at 922.

139. See Howard, supra note 55, at 405-06. 
traditional context may lead to results quite different from those one finds in the country from which the proposition was borrowed." 140 Positive rights, perhaps dangerous luxuries in the developed world and never gentle on the rule of law, may be toxic in East Africa. It is one thing for nations, having developed and become wealthy in the context of the rule of law, to afford not only the welfare state but also positive welfare rights. It is quite another to hobble efforts to establish the rule of law in the first place by subscribing to the general concept of positive rights, thereby compromising the very development and wealth production essential to satisfying the substance of those rights.

Sadly, the East African embrace of positive rights perpetuates a sort of imperialism, with developed nations pressuring developing nations to conform their legal systems to those of the former. While the same may be said of reform to create and support the rule of law, ${ }^{141}$ the benefits of the rule of law for developing nations render that brand of imperialism more a welcome helping hand. ${ }^{142}$ With positive rights, imperialism smacks more of domination - or perhaps of ineptitude - than of benign solicitude. International pressure to grant positive rights perversely maintains the leverage developed nations have over developing nations like those in East Africa.

The rule of law is too important, especially to developing countries, to be crippled by an overbroad concept of human rights. Positive human rights against civil government are likely to impede and not foster human welfare. ${ }^{143}$ The rule of law has much to do with that welfare. ${ }^{144}$ Nor is it

140. Id. at 403 .

141. See e.g., Brooks, supra note 11, at 2280.

142. See Rachel Kleinfeld, Advancing the Rule of Law Abroad: Next GENERATION REFORM 64-72 (2012).

143. "As numerous scholars have pointed out, there is no correlation between the constitutional language of social [i.e., positive] rights and the extent of welfare benefits provided by the state." Pascal, supra note 53, at 888 (footnoted omitted). Furthermore, a civil government can spend lavishly on social welfare programs without entailing positive rights to that spending, and even apart from such lavish spending (or despite it) a nation and its citizens can enjoy wealth. The protections of negative rights against civil governments necessarily involve the conduct of civil government, but the provision of the goods thought to be secured by positive rights against civil government can come from sources other than civil government. And even if goods come from civil government, they need not be provided as the fulfillment of positive rights against civil government. 
clear that for civil government itself actually to provide the objects of private rights truly advances human welfare. ${ }^{145}$ In fact, with the rule of law in place, the civil government fosters the play of other institutions far more effective in satisfying human needs, and often more effective by virtue of operating outside the constraint of the rule of law. ${ }^{146}$ A civil government that secures the rule of law has gone a long way to securing human welfare, and especially the welfare of the poor. ${ }^{147}$ Granting positive rights is a step in another direction.

These facts undercut such arguments for positive rights as, "It is trite but true that many traditional civil liberties are illusory to those living in poverty," Scott \& Macklem, supra note 58 , at 85 , and

Perhaps the strongest reason for including a certain number of [typically positive] economic and social rights is that by constitutionalizing half of the human rights equation [i.e., typically negative rights] South Africans would be constitutionalizing only part of what it means to be a full person. A constitution containing only civil and political rights projects an image of truncated humanity. Symbolically, but still brutally, it excludes those segments of society for whom autonomy means little without the necessities of life.

Id. at 29.

144. See supra note 27 and accompanying text.

145. See Robert Nisbet with Ross Douthat, The Quest for Community: A STUdy IN THE ETHICS OF ORDER AND FREEDOM (Intercollegiate Studies Institute 2010) (1953).

146. One thinks of enterprising businesses and also of charities free to develop enriching relationships with people as unique individuals. ("Governmental welfare programs need to be fought not because they are too expensive - although, clearly, much money is wasted - but because they are inevitably too stingy in what is really important, treating people as people and not animals." MARvin Olasky, The TRAgEDY OF AMERICAN COMPASSION 232-33 (1992).). The rule of law fosters both. See supra note 7 and accompanying text.

147. Gary Haugen, The Locust Effect (2014). 